Розділ І. Ціннісні орієнтири духовно-інтелектуального виховання, розвиток духовно-інтелектуальних якостей особистості в умовах співпраці й інклюзії

\title{
ОСОБЛИВОСТІ ОРГАНІЗАЦЇ̈ ФІЗИЧНОГО ВИХОВАННЯ ДІТЕЙ МОЛОДШОГО ШКІЛЬНОГО ВІКУ З ПОРУШЕННЯМИ ПОСТАВИ
}

\author{
Спіцин В. В. \\ кандидат педагогічних наук, доцент,
}

Харківська державна академія фізичної культури, м. Харків, Україна

Мова йде про визначення організаційно-педагогічних умов використання засобів і методів фізичного виховання, спрямованих на профілактику та корекцію порушень постави у дітей молодшого икільного віку. При застосуванні спеціально підібраних комплексів фізичних вправ, рухливих ігор і систематичного виконання домашнього завдання, у дітей молодшого шкільного віку з порушеннями постави відбувається покращення їх фізичного розвитку.

Ключові слова. Постава, профілактика, урок, фізична культура.

We are talking about determining the organizational and pedagogical conditions for the use of physical education tools and methods aimed at preventing and correcting postural disorders in primary school children. When using specially selected sets of physical exercises, outdoor games and systematic homework, primary school children with postural disorders improve their physical development.

Keywords. Posture, prevention, lesson, physical education.

Високий рівень поширеності хвороб кістково-м'язової системи серед школярів вимагає особливої уваги до профілактики порушень постави у дітей молодшого шкільного віку. Причини порушення опорно-рухового апарату можуть виникати в період інтенсивного росту та розвитку організму в умовах високого рівня статичного, сенсорного та інформаційного навантаження, низького рівня загальної рухової активності, незбалансованого харчування, відсутності спеціальних вправ для укріплення м’язового корсета, невідповідності організації фізичного виховання морфофункціональним особливостям та ступеню індивідуальної тренованості організму дитини, а також, невідповідності шкільних меблів та домашнього робочого місця росту дитини та інших факторів.

Аналіз науково-педагогічних джерел свідчить про те, що виховання правильної постави у дітей молодшого шкільного віку в основному проблема педагогічна, як і формування всіх життєво необхідних рухо- 
вих навичок. Багато дослідників, а саме, Н. Белякова (2003), О. Бурових (2003), О. Дубогай (2005), С. Голяка (2020), I. Моляренко (2020), С. Возний (2020) та ін., приходять до єдиної думки, що заклади освіти можуть і повинні бути місцем профілактики порушень постави в учасників освітнього процесу.

Метою статті - визначення організаційно-педагогічних умов використання засобів і методів фізичного виховання, спрямованих на профілактику та корекцію порушень постави у дітей молодшого шкільного віку.

У дослідженні взяли участь учні 4 класів (10 хлопчиків), які мали порушення постави, але за станом здоров'я не відносилися до спеціальної медичної групи. Усі порушення постави у дітей стали в наслідок слабкості та незбалансованості м'язового корсета.

Для вирішення завдань дослідження застосовувались наступні методи: теоретичний аналіз і узагальнення даних науково-методичної літератури, педагогічний експеримент, антропометричні вимірювання, педагогічні контрольні випробування, методи математичної статистики.

Порушення постави у школярів було виявлено за допомогою методики Ф. Штаффеля під час медичного огляду на початку навчального року.

Експериментальна група дітей молодшого шкільного віку протягом навчального року займалася фізичними вправами за окремою методикою, де навчання проводилися на основі комплексів коригувальної гімнастики при порушеннях постави, які складаються з симетричних, асиметричних, загальнорозвиваючих вправ, вправ на розтягування хребта, а також гімнастичних комплексів оздоровчих вправ для хребта. Вправи даних гімнастичних комплексів надають неоднаковий вплив на симетрично розташовані м'язи тулуба, які в результаті деформації перебувають в фізіологічно неврівноваженому стані.

Після виконання гімнастичних комплексів проводилися рухливі ігри, які сприймалися дітьми як розваги й забави, але дозволяли ненав’язливо вирішувати безліч корекційно-розвиваючих завдань, ініціюючи активність дітей.

По закінченню занять учні отримували картки з домашнім завданням для самостійної роботи. У картках домашніх завдань були розроблені комплекси, які включали коригувальні, деторсійні вправи й вправи, що спрямовані на розтягування хребта. 
Розділ І. Ціннісні орієнтири духовно-інтелектуального виховання, розвиток духовно-інтелектуальних якостей особистості в умовах співпраці й інклюзії

Зазначимо, що на початку і наприкінці експериментального дослідження нами були проведені вимірювання антропометричних показників дітей експериментальної групи (зріст, вага, окружність грудної клітки - ОГК) та визначення їх рівня фізичного розвитку (силова витривалість м'язів розгиначів спини, силова витривалість м'язів живота, статична витривалість м'язів живота), що дозволило виявити зміни у фізичному розвитку у цей період.

Динаміка змін антропометричних показників та рівня фізичного розвитку дітей молодшого шкільного віку експериментальної групи протягом педагогічного експерименту свідчить про те, що відбулися позитивні зміни за всіма показниками, які вірогідні у чотирьох випадках $(\mathrm{p}<0,05)$, а саме: окружність грудної клітки, силова витривалість м'язів розгиначів спини, статична витривалість м'язів черевного преса, силова витривалість м'язів черевного преса.

Показники зросту і ваги учасників протягом педагогічного експерименту збільшилися, але відмінності показників отриманих в дослідженні виявилися не вірогідні (p>0,05). Це говорить про те, що не зважаючи на спеціально підібрані вправи, корекційні ігри й домашнє завдання, для зміни даних показників виявилося недостатньо часу (табл.).

У результаті дослідження нами було встановлено, що дана програма вплинула на поліпшення якісних показників постави в учасників експериментальної групи. Застосування системи домашніх завдань додатково до даної програми привело до більш суттєвих позитивних зрушень в стані корегування постави.

Встановлений високий рівень порушень постави у дітей молодшого шкільного віку вказує на необхідність постійної й систематичної роботи з профілактики даних порушень з урахуванням їх характеру починаючи з першого класу. Роботу з профілактики порушень постави необхідно проводити в наступних напрямках: по-перше, на підвищення рівня знань 3 даного питання; по-друге, на формування навички правильної постави на кожному занятті з фізичного виховання; потретє, на зміцнення певних груп м’язів. Для цього необхідно включати в традиційні розділи навчальної програми матеріал по профілактиці порушень постави й організовувати та контролювати виконання домашніх завдань по зміцненню і корегуванню м’язового корсета та формуванню навичок правильної постави. 


\section{Антропометричні показники та показники \\ рівня фізичного розвитку}

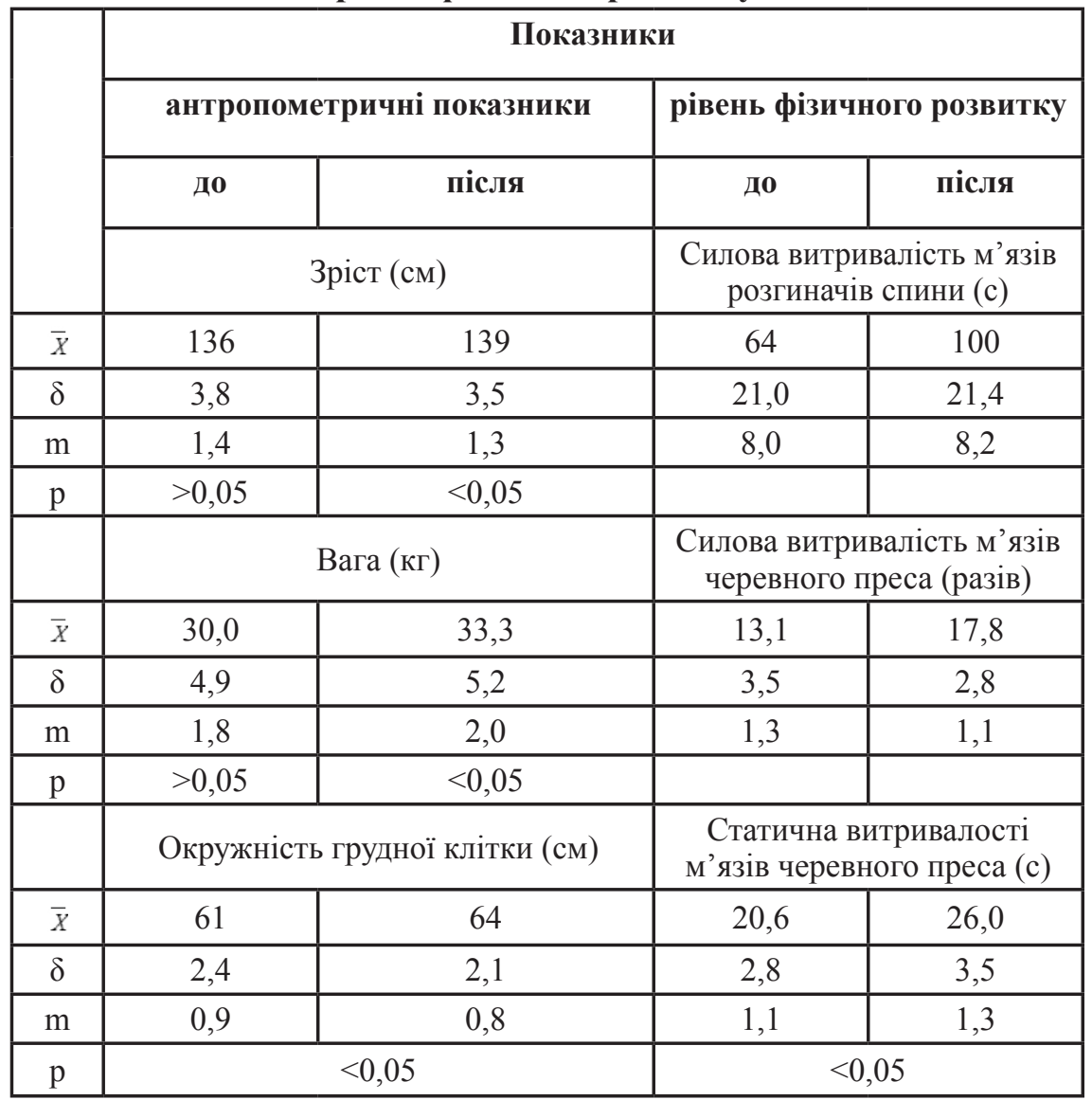

Перспективи подальших досліджень вбачаємо у вивченні питання щодо організації самостійних та дистанційних занять 3 фізичного виховання дітей молодшого шкільного віку з порушеннями постави.

\section{Список використаних джерел:}

1. Сфіменко П., Каніщева О. Особливості проведення реабілітаційного масажу при дисфункціях м'язів передпліччя. Слобожанський науковоспортивний вісник. 2021. № 2(82). С. 57-62. 
2. Бичук О. І. Біомеханічний контроль постави школярів у процесі фізичного виховання : автореф. дис. ... канд. наук з фіз. вих. і спорту : 24.00.02. Львів, 2001. 19 с.

3. Вільчковський Е. С. Організація рухового режиму дітей 5-10 років у закладах освіти. Запоріжжя, 2006. 228 с.

4. Вільчковський Е. С, Курок О. І. Теорія і методика фізичного виховання дітей дошкільного віку : навч. посіб. Суми : ВТД «Університетська книга», 2004. 438 c.

5. Денисенко Н. Ф. Управління системою фізичного виховання дітей у дошкільних навчальних закладах. Запоріжжя : Ліпс ЛТД, 2001. 308 с.

6. Денисенко Н. Ф., Григоренко Г. І., Михайліченко А. Ф. Дитячі народні рухливі ігри. Дніпропетровськ : Генеза-Південь, 2004. 213 с. 